\title{
Customer Satisfaction in Luxury Hotels in Hong Kong: Investigate the role of Service Quality
}

\author{
Anthony Tik-Tsuen WONG \\ School of Computing and Information Sciences \\ Caritas Institute of Higher Education \\ Hong Kong
}

\begin{abstract}
Hong Kong is a tourist hub with a famous name tag "Asia's World City". Hong Kong attracts variety of consumers from all around the world and the tourism industry needs to do research about the factors that are affecting customer satisfaction in Hong Kong luxury hotel industry. This study proposed a SEM approach to find out the relationship among perceived quality, service quality, tangibles, reliability, responsiveness, assurance, empathy that affecting customer satisfaction to luxury hotels in Hong Kong. The research framework of this study consists of three constructs including perceived quality, service quality, and customer satisfaction. Seven hypotheses are proposed to study and four hypotheses are accepted. Three hypotheses are rejected and to have no significant relationship with customer satisfaction in this study. At last, the relationship among seven hypotheses affecting on customer satisfaction are discussed and suggestions for unsupported hypotheses in context of enhancing customer satisfaction in Hong Kong luxury hotels are discussed as well.
\end{abstract}

Keywords: customer satisfaction, service quality, hotel, Hong Kong, structured equation modeling

\section{Introduction}

Hong Kong is a booming financial economy as well as a tourist hub with a famous name tag "Asia's World City". It is one of the gateways for in and out flow of business and tourism to around the world in Asian territory. Hong Kong attracts variety of consumers from all around the world and the tourism industry needs the research of the factors that are affecting customer satisfaction in the luxury hotel industry in Hong Kong. One of the contributing factors for Hong Kong's rising economic and tourism success is, annually hosting the world's renowned fairs and exhibitions at Hong Kong Convention and Exhibition Centre (HKCEC) held by Hong Kong Trade Development Councils (HKTDC). Notable trade-shows and fairs are Art Basel Hong Kong, Hong Kong Jewelry Show, Hong Kong Electronics Show and many more. Hong Kong has a reputable recognition in the global trade industry, as a result the city attracts repetitive buyers and sellers from all over the world at these fairs and exhibitions. Hong Kong Convention and Exhibition Centre (HKCEC) official venue for the fairs and exhibitions is surrounded by luxury hotels (Grand Hyatt Hong Kong, Renaissance Hong Kong Harbour View Hotel), many overseas exhibitors and buyers stay in above mentioned luxury hotels as it is at short walking distance from the venue.

Luxury hotels provide more services to consumers than budget hotels. Budget hotels are mainly diverted on providing basic hoteling necessity such as a simple, ordinary room setup and facilities with likewise beds and appliances as well as food and beverage services. Commonly backpackers and budget conscious travelers are the one who prefer such hotels as their resting service when travelling. On the other hand, luxury hotels aim to overlook the variable factors of price and provide "high-end" services which sometimes are above and beyond the customer's expectation. Lavish services at the luxury hotels are, extensive luxurious suites equipped with high-end furniture, fancy electronic appliances, in and outdoor extensive swimming pools, fancy spas and jacuzzi and valet services. Mainly wealthy lavish lifestyle consumers, business travelers and people who are travelling with their family and children will stay at luxury hotels. 


\subsection{Structure of the Study}

In this research, a review of the literature on customer satisfaction in the context of the luxury hotels industry in Hong Kong was done. Following are the seven hypotheses formulated from three constructed factors (perceived quality, service quality with SERVQUAL model and customer satisfaction) based on the research framework of the quantitative study. Moreover, the research methods are sampling of 200 luxury hotel(s) guests across Hong Kong who were questioned at random through self-administered questionnaires to determine the research outcome. At the end, data analysis was performed by using the structural equation modelling (SEM) after all the data was collected from 200 sampling respondents to determine the relationship between perceived quality, service quality and customer satisfaction of Hong Kong luxury hotels.

\subsection{Objective of the Research}

The purposes of this research are to study the factors that are affecting customer satisfaction in Hong Kong luxury hotels. It is significant to conduct a "quantitative" research methodology on those factors because customer satisfaction leads to a positive retention of customer. There are many research on factors affecting perceived quality, service quality and customer satisfaction in budgeted hotels worldwide but very few on luxury hotels. As there are none conducted in Hong Kong, this research will probably be the first study in the city's luxury hotel industry.

\section{Literature Review}

The following description provides a summary of literature review related to perceived quality, service quality, and customer satisfaction in the context of the luxury hotels industry in Hong Kong.

\subsection{Customer Satisfaction}

Customer satisfaction is a business philosophy which tends to be the creation of value for customers, anticipating and managing their expectations, and demonstrating ability and responsibility to satisfy their needs (Dominici and Guzzo, 2010). Customer satisfaction is a vital factor of creating and maintaining long term relationship with consumers. Customers are more likely to purchase the same product and service again of the brand if they are delighted with it and ignored other brands that have not met their expectations (Tabaku and Cerri, 2016). According to Anderson, Fornell and Lehmann (1994), customer satisfaction requires experience of service which is influenced by perceiving service quality. Lai, Griffin and Babin (2009) reveals that service quality of a telecommunication sector influences the perceived value positively, which in turn affects customer satisfaction positively, and Yang and Peterson (2004) reveals that companies should focus on increasing customer satisfaction and value perception in order to have customers satisfaction.

\subsection{Perceived Quality}

Perceptions of hotel service quality are the degree to which hotel guests find various hotel attributes important in enhancing their satisfaction and customer value is more and more important towards a successful business (Marković and Raspor, 2010). According to Zeithaml (1988), perceived value is a customer's overall assessment of the utility of a product which based on perceptions of what is received and what is given, their study also stated that the perceived quality is different from objective or actual quality, a higher level abstraction rather than a specific attribute of a product, a global assessment that in some case resembles attitude, and a judgement usually made within a consumer's evoked set. Perceived service quality in hotel industry appears to be reliability of the employees and must be tangible. Hotel guests usually perceive service quality as reliable and error-free, with courteous, professional and neat hotel employees and visually appealing physical facilities (Marković and Raspor Janković, 2013). Edvardsson (2005) reveals that customer's favourable / unfavourable or positive / negative experience may have an important impact towards perceived service quality. It is not only the customers' expectation, but also the delivery process and service outcome that are also important in perceived service quality (Ghobadian, Speller and Jones, 1994). In order to minimise the gap between the guests' expectations and their perceptions of actual service delivered, the managers and personnel in the hotel have to ensure that every contact with guests results in positive experience for the guests (BLEŠIĆ et.al, 2011). Therefore, a hypothesis is proposed below:

Hypothesis H1: The effect of perceived value on service quality is significant. 


\subsection{Service Quality}

Service quality is measured by multiple dimensions and each dimension may influence the overall assessment of service quality from the customers' perspective (Gumussoy and Koseoglu, 2016). The study by Parasuraman, Zeithaml and Berry (1988) divided the service quality into a SERVQUAL model: tangibles (physical facilities, equipment, and appearance of personnel), reliability (ability to perform the promised service dependably and accurately), responsiveness (willingness to help customers and provide prompt service), assurance (knowledge and courtesy of employees and their ability to inspire trust and confidence), and empathy (caring, individualized attention the firm provides to its customers). SERVQUAL model is an assessment tool for service quality which enables management to better understand the various dimensions and how they affect service quality and customer satisfaction (Debasish and Dey, 2015). Based on the literatures, several empirical studies found the linkage between customer satisfaction with each dimension of the SERVQUAL model, Marković and Raspor Janković (2013) commented that tangibles component of SERVQUAL model influences customer satisfaction because of the visually appealing physical facilities and materials such as pleasant surrounding, fabulous location, great rooms, green and tropical surrounding, relaxing pool (Karunaratne and Jayawardena, 2010). Wong, Dean and White (1999) identified tangible dimension to be significant with managers of the hotels to have up-to-date fixtures and fittings. Therefore, a hypothesis is proposed below:

\section{Hypothesis H2: The effect of tangible component of service quality on customer satisfaction is significant.}

In addition, responsiveness component of the SERVQUAL model influences customer satisfaction because of the importance the hotel's willingness and flexibility to serve and help customers (Minh et al., 2015) such as the information counter, travel desk or ticketing counter, welcoming of customers in a customised manner, and orienting them to different services rendered by the hotel (Karunaratne and Jayawardena, 2010). Therefore, a hypothesis is proposed below:

\section{Hypothesis H3: The effect of responsiveness component of service quality on customer satisfaction is significant.}

Moreover, empathy component of SERVQUAL model influences customer satisfaction as a result of the customers' expectations on their sensitivity to demands and flexibility of hotel staff (Karunaratne and Jayawardena, 2010). Al Khattab and Aldehayyat (2011) reveals that hotels must understand that all customers are not the same which indicates the potential importance of market segmentation such as grouping customers sharing similar requirements, expectations and demographic profiles. Therefore, a hypothesis is proposed below:

\section{Hypothesis H4: The effect of empathy component of service quality on customer satisfaction is significant.}

Further, reliability component of SERVQUAL model influences customer satisfaction because the hotel managers should continue to insist on error-free service that is delivered in the promised time, and guests' problems should be solved in an appropriate way in order to deliver satisfactory service to their guests (Marković and Raspor Janković, 2013). Therefore, a hypothesis is proposed below:

H5: The effect of reliability component of service quality on customer satisfaction is significant.

Additionally, assurance component of SERVQUAL model influences customer satisfaction due to it regards to customers' feeling safe and secure, staff's knowledge of surrounding areas, staff's occupational skills and staff's courteous attitude (Minh et al., 2015). Therefore, a hypothesis is proposed below:

\section{Hypothesis H6: The effect of assurance component of service quality on customer satisfaction is significant.}

At last, service quality as a whole impacts customer satisfaction and it is expected that as long as the quality of services improves, there will be more satisfied customers (Gumussoy and Koseoglu, 2016). Therefore, a hypothesis is proposed below:

Hypothesis H7: The effect of service quality on customer satisfaction is significant. 


\subsection{Research Framework}

The research framework of this study is shown in Figure.1. The hypotheses of the research framework are constructed based on the literature reviews about perceived quality, service quality, and customer satisfaction respectively.

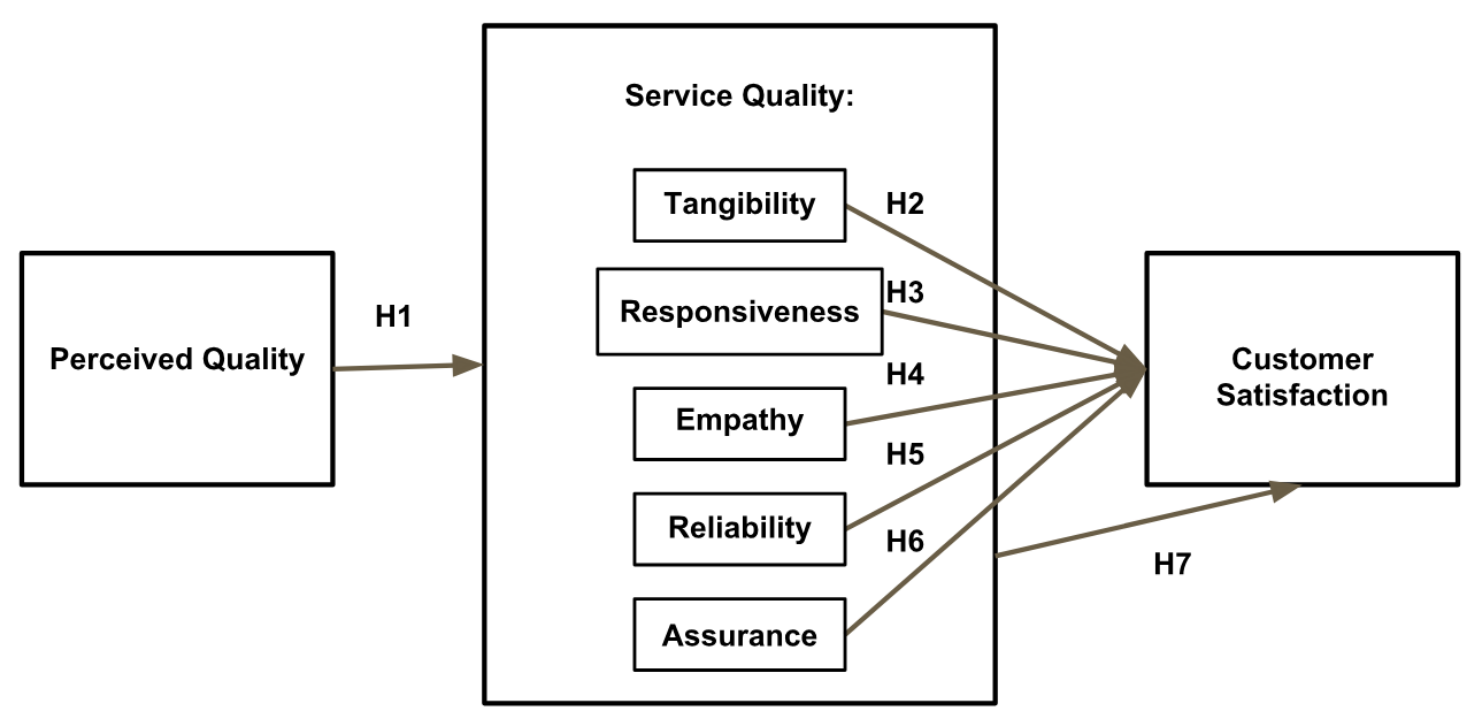

Figure.1 Research Framework

\section{Research Methodology}

The research methodology of this study is in quantitative. A questionnaire survey of 200 respondents and statistical analysis of the collected data was done by using structural equation modelling.

\subsection{Sampling}

The research studied 200 respondents who were staying at luxury hotels in Hong Kong with age over 18. Although luxury hotels have wide range of ages of customers, the research was only to collect data from adults who are aged over 18 because they are mature, objective to evaluate things and are more suitable for the research. The research aims to collect factual data because adults who are aged over 18 are the decision maker of choosing a hotel.

\subsection{Data Collection Method}

The respondents were invited for the questionnaires at random. Afterwards, respondents were required to fill in a questionnaire face-to-face with the researcher and returned it upon completion. The questionnaire were conducted near the luxury hotels. The Peninsula and Intercontinental Hong Kong in Kowloon and the hotels in Hong Kong Island: Four Seasons, Grand Hyatt and Island Shangri-la, Hong Kong. The guest of the luxury hotel were questioned on the sidewalks near the luxury hotels as permission of conducting within the hotel premises was not granted. Customers were randomly selected and invited. They were staying in the luxury hotels of any gender, Asians, Westerners, Europeans and etc.

\subsection{Research Instruments}

There are three constructs in the research framework. They are perceived quality, service quality and customer satisfaction. An eight-section self-administered questionnaire is used to collect quantitative data. The first section collected the responses about the measurement for perceived quality; the other six sections collected the responses of the measurement of service quality with SERVQUAL model whilst the last section collected the responses on the measurement of customer satisfaction.

\subsubsection{Measurement for Perceived Quality}

The research conceptualized perceived quality of luxury hotel customers in Hong Kong as the key influence on service quality and customer satisfaction.

Table 1. Measuring items for Perceived Quality (BLEŠIĆ et.al, 2011) 


\begin{tabular}{|c|c|l|}
\hline Construct & Item & \multicolumn{1}{|c|}{ Questions } \\
\hline \multirow{2}{*}{\begin{tabular}{c} 
Puality \\
\cline { 2 - 3 }
\end{tabular}} & PQ2 & The hotel staff provide individual care of guest. \\
\cline { 2 - 4 } & PQ3 & The hotel location is accessible. \\
\cline { 2 - 4 } & PQ4 & The hotel staff shows readiness to help the guest. \\
\cline { 2 - 4 } & PQ5 & The hotel staff provide service in promised manner of time. \\
\hline
\end{tabular}

Perceived quality is measured by using a five-item adapted from Bradić et.al, (2011). Table 1 above shows these measurement items, the question ID and the questions relating to perceived quality. There were 24 question items in the research by Bradić et.al, (2011) but five question items were adapted to this research which are related to the study of this research. Those questions were adapted from Bradic et.al, (2011) by modify the key words to hotel staff are professional, hotel location is accessible and etc.

\subsubsection{Measurement for Service Quality (SERVQUAL Model)}

The research conceptualised service quality in multiple dimensions using the SERVQUAL model of luxury hotel customers in Hong Kong because it influences the overall customer satisfaction.

Table 2. Measuring items for Service Quality - Tangibles (Debasish and Dey, 2015)

\begin{tabular}{|c|c|l|}
\hline Construct & Item & \\
\hline $\begin{array}{c}\text { Service } \\
\text { Quality } \\
\text { (Tangibles) }\end{array}$ & $\mathrm{T} 1$ & The hotel has adequate facilities and supplies. \\
\cline { 2 - 4 } & T2 & The hotel has visually appealing facilities. \\
\cline { 2 - 4 } & T3 & $\begin{array}{l}\text { The hotel has visually appealing materials (pamphlets, websites, statements, } \\
\text { etc). }\end{array}$ \\
\cline { 2 - 4 } & T4 & The hotel has neat, clean and tidy premises. \\
\cline { 2 - 4 } & T5 & The hotel has large parking area. \\
\hline
\end{tabular}

The component tangibles of SERVQUAL model is measured using a five-item adapted from Debasish and Dey (2015). Table 2 above shows these measurement items, the question ID and the questions relating to tangibles. The questions were adapted from Debasish and Dey (2015) by revising the key words to, such as hotel has adequate facilities and supplies, the hotel has large parking area and etc.

Table 3. Measuring items for Service Quality - Responsiveness (Minh et al., 2015) 


\begin{tabular}{|c|c|l|}
\hline Construct & Item & \multicolumn{1}{c|}{ Questions } \\
\hline $\begin{array}{c}\text { Service } \\
\text { Quality } \\
\text { (Responsiveness) }\end{array}$ & $\mathrm{R} 1$ & The hotel staff is willing to serve guest. \\
\cline { 2 - 4 } & $\mathrm{R} 2$ & The hotel staff is available to guest requests. \\
\cline { 2 - 4 } & $\mathrm{R} 3$ & The hotel staff is flexible according to guest demands. \\
\hline
\end{tabular}

The component responsiveness of SERVQUAL model is measured using a three-item adapted from Minh et al. (2015). Table 3 above shows these three measurement items, the question ID and the questions relating to responsiveness. The questions were adapted from the research by Minh et al. (2015) by modifying the key words of the questions to, such as willing to provide service to guest, hotel staff is willing to serve guest, hotel staff is available to guest's requests, and etc.

Table 4. Measuring items for Service Quality - Empathy (Al Khattab and Aldehayyat, 2011)

\begin{tabular}{|c|c|l|}
\hline Construct & Item & \\
\hline \multirow{2}{*}{$\begin{array}{c}\text { Quality } \\
\text { (Empathy })\end{array}$} & E2 & The hotel staff provides the guest personal attention. \\
\cline { 2 - 4 } & E3 & The hotel staff have best interest of the guest at heart. \\
\cline { 2 - 4 } & E4 & The hotel staff understand the guest specific needs. \\
\cline { 2 - 4 } & E5 & The hotel staff is competent. \\
\hline
\end{tabular}

Empathy is another component of the SERVQUAL model and is measured using a five-item adapted from Al Khattab and Aldehayyat (2011). Table 4 above shows these measurement items, the question ID and the questions relating to empathy. The questions were adapted from Al Khattab and Aldehayyat (2011) by using the key words to, such as the hotel staff has knowledge to guest questions, the hotel staff provides the guest personal attention and etc.

Table 5. Measuring items for Service Quality - Reliability (Marković and Raspor Janković, 2013)

\begin{tabular}{|c|c|l|}
\hline Construct & Item & Questions \\
\hline \multirow{2}{*}{$\begin{array}{l}\text { Service } \\
\text { Quality }\end{array}$} & Y1 & The hotel performs the service in promised time. \\
\cline { 2 - 3 } & Y2 & The hotel staff provides service without delay. \\
\hline
\end{tabular}


The component, reliability of SERVQUAL model is measured by using a three-item adapted from Marković and Raspor Janković (2013). Table 5 above shows these measurement items, the question ID and the questions relating to reliability. The questions were adapted from Marković and Raspor Janković (2013) by revising the key words to, such as hotel performs the service in promised time, the hotel staff provides service without delay, etc.

Table 6. Measuring items for Service Quality - Assurance (Minh et al., 2015)

\begin{tabular}{|c|c|l|}
\hline Construct & Item & \multicolumn{1}{c|}{ Questions } \\
\hline $\begin{array}{c}\text { Quality } \\
\text { (Assurance) }\end{array}$ & A1 & The hotel provides feelings of safe and secure during guest stay. \\
\cline { 2 - 3 } & $\begin{array}{l}\text { The hotel staff provides knowledge to guests information about } \\
\text { surrounding areas (museum, shopping, place of interests, etc). }\end{array}$ \\
\cline { 2 - 3 } & A3 & The hotel staff has occupational skills. \\
\cline { 2 - 3 } & A4 & The hotel staffs are courteous and polite. \\
\hline
\end{tabular}

Assurance is the component of SERVQUAL model and is measured using a four-item adapted from Minh et al. (2015). Table 6 above shows these four measurement items, the question ID and the questions relating to assurance. The questions were adapted from Minh et al. (2015) by modifying the key words to, such as the hotel provides feelings of safe and secure during guest stay, the hotel staff has occupational skills and etc.

Table 7. Measuring items for Service Quality (Tabaku and Cerri, 2016)

\begin{tabular}{|c|c|l|}
\hline Construct & Item & \multicolumn{1}{c|}{ Questions } \\
\hline $\begin{array}{l}\text { Service } \\
\text { Quality }\end{array}$ & SQ1 & The services provided at the hotel meets the guest expectation. \\
\cline { 2 - 3 } & SQ2 & The guest is satisfied with hotel services. \\
\hline
\end{tabular}

Service quality is measured using a two-item adapted from Tabaku and Cerri (2016). Table 7 above shows these measurement items, the question ID and the questions relating to service quality. The questions were adapted from Tabaku and Cerri (2016) by using the key words to, such as services provided at the hotel meets the guest expectations and hotel guest is satisfied with hotel provided service.

\subsubsection{Measurement for Customer Satisfaction}

The research conceptualized customer satisfaction of luxury hotel customers in Hong Kong is influenced by perceived quality and service quality. 
Table 8. Measuring items for Customer Satisfaction (Gumussoy and Koseoglu, 2016)

\begin{tabular}{|c|c|l|}
\hline Construct & Item & \multicolumn{1}{|c|}{ Questions } \\
\hline Customer & CS1 & The choice of this hotel is a wise idea. \\
\cline { 2 - 3 } Satisfaction & CS2 & The guest is satisfied with the decision to visit this hotel. \\
\hline
\end{tabular}

Customer satisfaction is measured by using a two-item adapted from Gumussoy \& Koseoglu (2016). Table 8 above shows the two measurement items, the question ID and the questions relating to customer satisfaction. The questions were adapted from Tabaku and Cerri (2016) by using the key words to formulate a structure to the questions such as hotel guest is satisfied with the decision to visit this hotel.

\subsubsection{Measurement of Demographic Characteristics}

Demographic information, such as, gender, age, marital status and education level are measured using nominal scales. Demographic information assists in establishing the representativeness of the population.

\subsection{Data Analysis}

The collected data was analyzed by the following statistical methods.

\subsubsection{Measurement Assessment}

Descriptive analysis, reliability and validity tests were conducted to evaluate the quality of the collected data prior to further analysis. Bartlett's test of sphericity and Kaiser-Meyer-Olkin (KMO) tests was conducted to assess the adequacy of sample size. The aforementioned tests are to ensure that the basic assumptions for further analysis are met (Coakes et al., 2008; Hair et al., 2005).

\subsubsection{Factor Analysis}

Confirmatory factor analysis (CFA) and exploratory factor analysis (EFA) were conducted on the variables of the research framework (perceived quality, service quality and customer satisfaction) to ensure the reliability and validity (Coakes et al., 2008; Hair et al., 2005) of the collected data.

\subsubsection{Structural Equation Modelling}

Reliability and validity tests are established to reinforce the data credibility. Structural equation modelling (SEM) is a measurement model that is used to test the significance of the research framework.

\section{Results of Analysis \\ 4.1 Sample Characteristics}

Table 9. Characteristics of the sample

Profile of survey respondents

\begin{tabular}{lrr}
\hline Category & Quantity & $\%$ \\
\hline Gender & & \\
Male & 119 & $59.9 \%$ \\
Female & 81 & $40.5 \%$ \\
Total & $\mathbf{2 0 0}$ & $\mathbf{1 0 0 \%}$
\end{tabular}




$\begin{array}{lrr}18-25 & 13 & 6.5 \% \\ 26-33 & 31 & 15.5 \% \\ 34-40 & 45 & 22.5 \% \\ 41-47 & 49 & 24.5 \% \\ 48-54 & 29 & 14.5 \% \\ 55-65 & 22 & 11.0 \% \\ 65 \text { or above } & 11 & 5.5 \% \\ \text { Total } & \mathbf{2 0 0} & \mathbf{1 0 0 \%}\end{array}$

\section{Marital Status}

\begin{tabular}{lrr} 
Married & 71 & $35.5 \%$ \\
Single & 129 & $64.5 \%$ \\
Total & $\mathbf{2 0 0}$ & $\mathbf{1 0 0 \%}$ \\
\hline
\end{tabular}

\section{Education}

Lower than High School

High School

Associate Degree/Higher Diplomas $\quad 18 \quad 9 \%$

Bachelors $\quad 126 \quad 63 \%$

Doctorate $\quad 50 \quad 25 \%$

$\begin{array}{lll}\text { Total } & 200 & 100 \%\end{array}$

\section{Region}

Asia Pacific

55

18

$27.5 \%$

Middle East

60

$9.0 \%$

Europe

Africa

America

Total
12

55

200
$30.0 \%$

$6.0 \%$

$25.5 \%$

$100 \%$

Table 9 summarised the sample characteristics of the respondents. In total 200 valid responses, 119 respondents were male, 81 were female. For the age, $6.5 \%$ of respondents were in age $18-25,15.5 \%$ were in age $26-33,22.5 \%$ were in age $34-40,24.5 \%$ were in age $41-47,14.5 \%$ were in age $48-54,11 \%$ were in age $55-65$, and $5.5 \%$ were in age 65 or above. For the marital status, $53.5 \%$ were married, $64.5 \%$ were single. For the education level, none of them were lower than high school level, $3 \%$ respondents were high school level, 9\% respondents were associated degree or higher diplomas level, 63\% respondents were bachelor level, 25\% respondents were doctorate level. For region, 27.5\% respondents were from Asia Pacific, 9\% respondents were from Middle East, 30\% respondents were from Europe, 6\% respondents were Africa, $25.5 \%$ respondents were from America. The descriptive analysis shows that there is not significant biased of demographics of the respondents.

\subsection{Model Analysis}

The present study began with the measurement model for examining the reliability and validity of the latent variables that based on the three perspectives suggested by Hulland (1999), which are individual item reliability, convergent validity and discriminant validity.

\subsubsection{Reliability and Validity}

Hulland (1999) noted that SmartPLS examines the individual item reliability by evaluating factor loadings of measurable variables on latent variables and suggested that any measurable variables with factor loading less than 0.5 should be deleted because a low factor loading can result in low reliability. Table 10 shows the original data that collected from the questionnaires which presents the average, standard deviation, loading, composite reliability (CR) and average variances extracted (AVE) calculated for assessing the scale reliability, but some results were not significant. For example from Table 10, the factor loading of Perceived 
Quality (PQ2) and Perceived Quality (PQ4) are 0.42 and 0.40 respectively, which were not significant to the entire result because of loading value below 0.5. By removing the responses of PQ2 and PQ4, and other questions with low loading value in other constructs (T1, T4, and A3), Table 11 presents the new average, standard deviation, loading, composite reliability (CR) and average variances extracted (AVE) calculated for assessing the scale reliability. The following would be discussed later.

Table 10. Reliability and validity analysis of latent variables

\begin{tabular}{|c|c|c|c|c|c|c|c|c|c|c|c|}
\hline \multicolumn{2}{|l|}{ Latent variable } & \multicolumn{3}{|c|}{ Measured variable } & \multirow{2}{*}{$\begin{array}{c}\text { Average } \\
4.31\end{array}$} & \multicolumn{3}{|c|}{ Standard deviation } & \multirow{2}{*}{$\begin{array}{c}\text { Loading } \\
0.78\end{array}$} & \multirow{2}{*}{$\begin{array}{l}\text { CR } \\
0.75\end{array}$} & \multirow{2}{*}{$\begin{array}{r}\text { AVE } \\
0.40\end{array}$} \\
\hline Perceived & & PQ1 & & & & & 0.53 & & & & \\
\hline Quality & PQ2 & & & 4.33 & & 0.62 & & 0.42 & & & \\
\hline PQ3 & & & 4.58 & & 0.50 & & 0.67 & & & & \\
\hline & & PQ4 & & & 4.48 & & 0.54 & & 0.40 & & \\
\hline PQ5 & & & 4.39 & & 0.52 & & 0.76 & & & & \\
\hline Tangibles & & T1 & & & 4.33 & & 0.56 & & 0.56 & 0.77 & 0.43 \\
\hline & & $\mathrm{T} 2$ & & & 4.31 & & 0.66 & & 0.81 & & \\
\hline & & $\mathrm{T} 3$ & & & 4.33 & & 0.68 & & 0.83 & & \\
\hline & & T4 & & & 4.81 & & 0.40 & & 0.30 & & \\
\hline & & T5 & & & 3.80 & & 0.66 & & 0.60 & & \\
\hline Responsivenes & & $\mathrm{R} 1$ & & & 4.47 & & 0.50 & & 0.80 & 0.75 & 0.51 \\
\hline & & $\mathrm{R} 2$ & & & 4.47 & & 0.54 & & 0.67 & & \\
\hline & & R3 & & & 4.32 & & 0.60 & & 0.66 & & \\
\hline Empathy & & E1 & & & 4.27 & & 0.55 & & 0.74 & 0.85 & 0.53 \\
\hline & & $\mathrm{E} 2$ & & & 4.31 & & 0.55 & & 0.68 & & \\
\hline & & E3 & & & 4.36 & & 0.54 & & 0.74 & & \\
\hline & & E4 & & & 4.26 & & 0.55 & & 0.79 & & \\
\hline E5 & & & 4.34 & & 0.53 & & 0.71 & & & & \\
\hline Reliability & & Y1 & & & 4.31 & & 0.54 & & 0.79 & 0.87 & 0.69 \\
\hline $\mathrm{Y} 2$ & & & 4.27 & & 0.56 & & 0.87 & & & & \\
\hline Y3 & & & 4.33 & & 0.53 & & 0.84 & & & & \\
\hline Assurance & & A1 & & & 4.79 & & 0.41 & & 0.62 & 0.69 & 0.28 \\
\hline $\mathrm{A} 2$ & & & 4.43 & & 0.60 & & 0.75 & & & & \\
\hline A3 & & & 4.35 & & 0.56 & & 0.40 & & & & \\
\hline A4 & & & 4.73 & & 0.44 & & 0.72 & & & & \\
\hline Service & SQ1 & & & 4.37 & & 0.48 & & 0.88 & 0.87 & 0.78 & \\
\hline Quality & SQ2 & & & 4.51 & & 0.51 & & 0.89 & & & \\
\hline Customer & & $\mathrm{CS} 1$ & & & 4.46 & & 0.51 & & 0.91 & 0.90 & 0.83 \\
\hline Satisfaction & & $\mathrm{CS} 2$ & & & 4.50 & & 0.50 & & 0.91 & & \\
\hline
\end{tabular}

Table 11. Reliability and validity analysis of latent variables

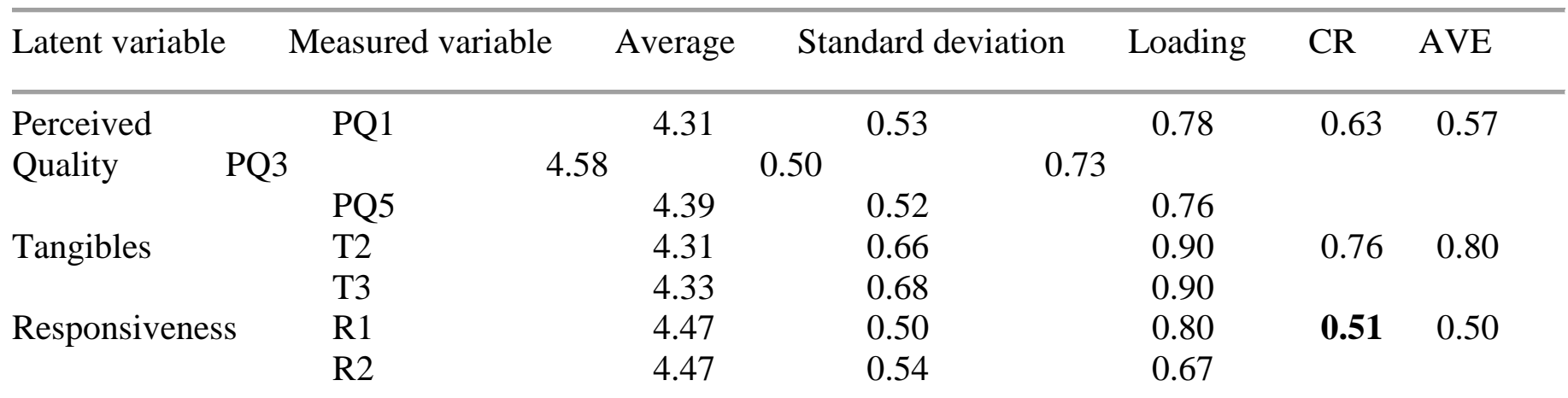




\begin{tabular}{|c|c|c|c|c|c|c|c|c|c|c|c|}
\hline \multirow{5}{*}{ Empathy } & & R3 & & & 4.32 & & 0.60 & & 0.66 & & \\
\hline & & E1 & & & 4.27 & & 0.55 & & 0.74 & 0.78 & 0.53 \\
\hline & & E2 & & & 4.31 & & 0.55 & & 0.65 & & \\
\hline & & E3 & & & 4.36 & & 0.54 & & 0.75 & & \\
\hline & & E4 & & & 4.26 & & 0.55 & & 0.79 & & \\
\hline E5 & & & 4.34 & & 0.53 & & 0.72 & & & & \\
\hline Reliability & & Y1 & & & 4.31 & & 0.54 & & 0.79 & 0.78 & 0.70 \\
\hline $\mathrm{Y} 2$ & & & 4.27 & & 0.56 & & 0.87 & & & & \\
\hline Y3 & & & 4.33 & & 0.53 & & 0.84 & & & & \\
\hline Assurance & & A1 & & & 4.79 & & 0.41 & & 0.66 & 0.55 & 0.52 \\
\hline A2 & & & 4.43 & & 0.60 & & 0.80 & & & & \\
\hline A4 & & & 4.73 & & 0.44 & & 0.70 & & & & \\
\hline Service & SQ1 & & & 4.37 & & 0.48 & & 0.88 & 0.71 & 0.78 & \\
\hline Quality & SQ2 & & & 4.51 & & 0.51 & & 0.89 & & & \\
\hline Customer & & $\mathrm{CS} 1$ & & & 4.46 & & 0.51 & & 0.90 & 0.79 & 0.83 \\
\hline Satisfaction & & $\mathrm{CS} 2$ & & & 4.50 & & 0.50 & & 0.91 & & \\
\hline
\end{tabular}

\subsubsection{Convergent and Discriminant Validity}

The constructs validity had been evaluated by convergent and discriminant validity based on criteria set and described as follows.

\subsubsection{Convergent Validity Criteria}

Table 11 indicates that all constructs had reached the criteria of discriminant validity. Composite reliability should exceed 0.7 and square root of AVE must be larger than the correlation coefficient of the construct with all other constructs. Table 11 shows that most of the composite reliability (CR) were more than 0.7 and the others (responsiveness and assurance) are not less than 0.51, the average variances extracted (AVE) are greater than the value of 0.5 . Table 11 also shows that the factor loading were from 0.65 to 0.91 . Although not all of them over 0.7 but most of them exceed 0.7 and the others are near 0.7 . Table 11 presents the highest value of factor loading for all indicator belongs to associated construct, the validity of the empirical data had been supported and the convergent validity has been achieved.

\subsubsection{Discriminant Validity Criteria}

Fornell and Larcker (1981) suggested that discriminating validity can be calculated by the square root of average variance extracted (SRAVE) of each latent variable and the correlation coefficient among latent variables. Discriminating validity exists when the SRAVE is greater than the correlation coefficient among the other latent variables. The calculated value of correlation coefficient for the latent variable itself will be bigger than with other latent variables. From Table 12, the correlation coefficient were calculated among all latent variables which are perceived quality, tangibles, responsiveness, empathy, reliability, assurance, service quality and customer satisfaction. Table 12 shows that the value of correlation coefficient of Assurance itself was 0.72 which is greater than other latent variables, such as 0.37 for customer satisfaction, or 0.18 for empathy. Also, 0.91 for customer satisfaction itself which is greater than 0.38 empathy and 0.33 of perceived quality.

Table 12. The SRAVE of each latent variable and the correlation coefficient among latent variables

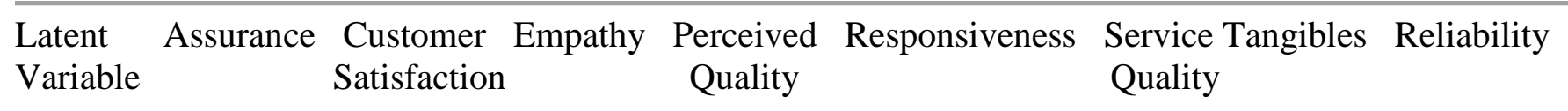

$\begin{array}{lll}\text { Assurance } & \mathbf{0 . 7 2} & \\ \text { Customer } & 0.37 & \mathbf{0 . 9 1} \\ \text { Satisfaction } & & \end{array}$




$\begin{array}{llll}\text { Empathy } & 0.18 & 0.38 & \mathbf{0 . 7 3}\end{array}$

$\begin{array}{llll}\text { Perceived } & 0.32 & 0.33 & 0.33 \quad \mathbf{0 . 7 6}\end{array}$

Quality

$\begin{array}{llllll}\text { Responsive } & 0.27 & 0.43 & 0.65 & 0.46 & \mathbf{0 . 7 1}\end{array}$

-ness

$\begin{array}{llllll}\text { Service } 0.26 & 0.67 & 0.46 & 0.44 & 0.47 & \mathbf{0 . 8 9}\end{array}$

Quality

$\begin{array}{llllllll}\text { Tangibles } & 0.50 & 0.40 & 0.38 & 0.24 & 0.35 & 0.30 & \mathbf{0 . 9 0}\end{array}$

$\begin{array}{lllllllll}\text { Reliability } & 0.01 & 0.27 & 0.60 & 0.35 & 0.45 & 0.41 & 0.20 & \mathbf{0 . 8 3}\end{array}$

\subsubsection{Path Coefficients and Result of the Hypotheses Tests}

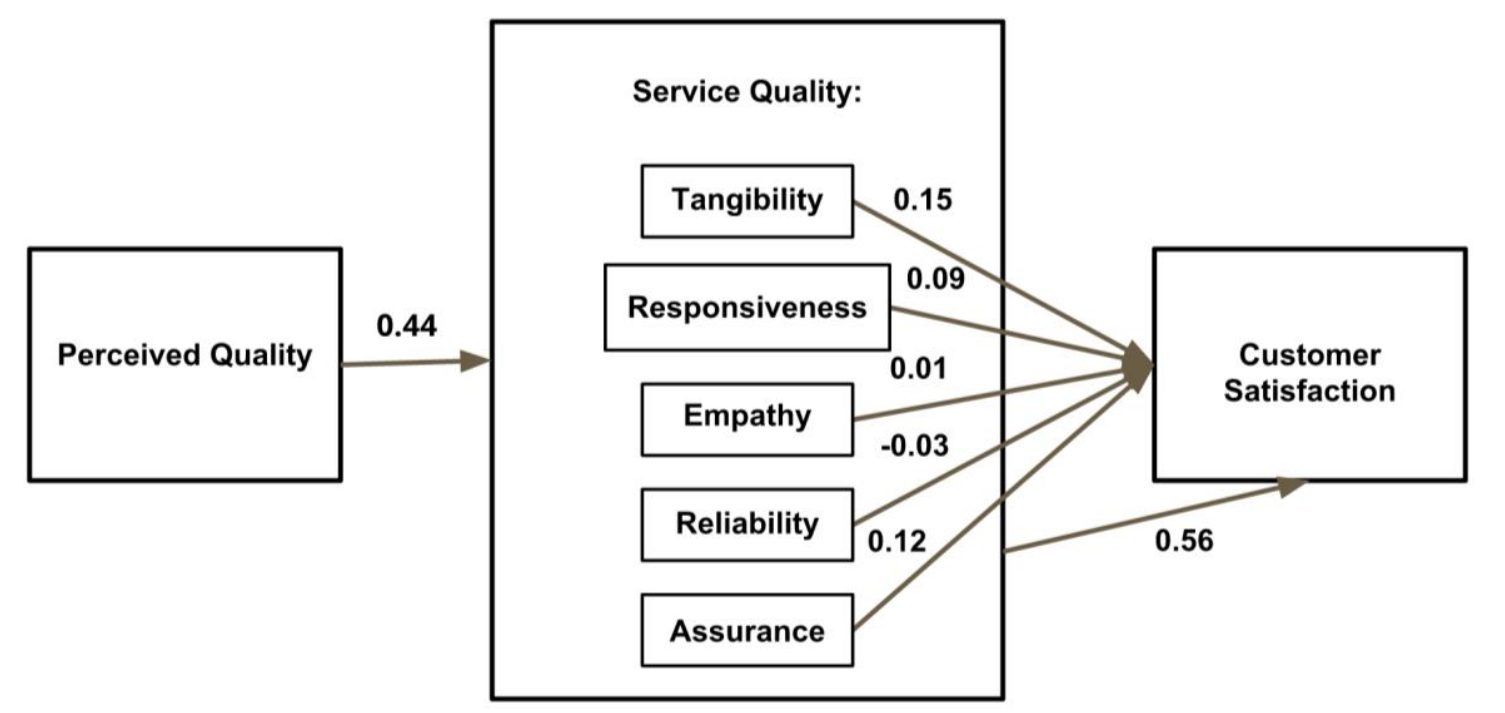

Figure 2. Structural Framework Analysis Result

Table 13. Path Coefficients and result of the hypotheses tests

\begin{tabular}{llllll}
\hline Hypothesis $\quad$ Path & $\begin{array}{l}\text { Path } \\
\text { coefficient }\end{array}$ & $t$ value & $p$ value & Result \\
& & & & \\
\hline H1. & Perceived Quality $\rightarrow$ Service Quality & 0.44 & 7.85 & $\mathbf{0 . 0 0 0}$ & Accept \\
H2. & Tangibles $\rightarrow$ Customer Satisfaction & 0.15 & 2.45 & $\mathbf{0 . 0 1 5}$ & Accept \\
H3. & Responsiveness $\rightarrow$ Customer Satisfaction & 0.09 & 1.21 & 0.228 & Reject \\
H4. & Empathy $\rightarrow$ Customer Satisfaction & 0.01 & 0.15 & 0.879 & Reject \\
H5. & Reliability $\rightarrow$ Customer Satisfaction & -0.03 & 0.47 & 0.638 & Reject \\
H6. & Assurance $\rightarrow$ Customer Satisfaction & 0.12 & 2.02 & $\mathbf{0 . 0 4 4}$ & Accept \\
H7. & Service Quality $\rightarrow$ Customer Satisfaction & 0.56 & 8.19 & $\mathbf{0 . 0 0 0}$ & Accept \\
\end{tabular}

Structural model analysis is used mainly to examine the path coefficients and $\mathrm{R}^{2}$ among latent variables in the research model. Path coefficients measure the relative strength and sign of causal relationships among latent variables, whereas $\mathrm{R}^{2}$ is the percentage of total variance explained of exogenous variable on 
endogenous variables and thus represents the predictability of the research model. Path coefficients and $\mathrm{R}^{2}$ represent the matching level between the structural model and experimental data. Figure 2 is the summary of the structural model analysis of this study. Table 13 shows the path coefficients, $t$ values and $p$ values among latent variables, and the results of the hypotheses test. According to Table 13, the test results for the hypotheses $\mathrm{H} 1, \mathrm{H} 2, \mathrm{H} 6$ and $\mathrm{H} 7$ are supported and significant (with p value lower than 0.05). The test results for the hypotheses $\mathrm{H} 3, \mathrm{H} 4$ and $\mathrm{H} 5$ are not supported with $\mathrm{p}$ value greater than 0.05 . The path coefficients of each supported hypothesis, $\mathrm{H} 1, \mathrm{H} 2, \mathrm{H} 6$ and $\mathrm{H} 7$ are $0.44,0.15,0.12$ and 0.56 respectively, which show that although $\mathrm{H} 1, \mathrm{H} 2, \mathrm{H} 6$ and $\mathrm{H} 7$ are supported, their effects are not strong and significant.

\section{Discussion}

This study reveals the relationship between significant effect of perceived quality to service quality and the effects to customer satisfaction. Gumussoy and Koseoglu (2016) revealed that a high percentage of perceived quality is predicted by service quality and further showed the positive significance. In order to reach the desired level of service, hotel managers should monitor the service provided to the customers. Customers expectations were higher than their perceptions of quality services in all factors (BLEŠIĆ et.al, 2011). This research reveals that the consumers are concerned with the hotel staff being professional, the hotel location needs to be accessible, and the service needs to perform in promised matter time. The hotel staff needs to be professional by providing quality service with a sense of knowing what they are doing. The location needs to be near or walking distances from the major transportation in Hong Kong such as MTR, taxi-stop, bus-stop. The service needs to performed in the promised matter of time by having no delays such as if the room was told to be ready in 30 minutes, than it should be ready in 30 minutes. Thus, the correlation of perceived quality is significant to service quality.

For the hypothesis related to tangibles affecting customer satisfaction, it is consistent with the research of Karunaratne and Jayawardena (2010) and it showed that hotel tangibility dimension scored +0.184 which was recorded the highest level of customer satisfaction. Debasish and Dey (2015) revealed that the main dimensions of perceived service quality in luxury hotels were found to be tangibility which explained high variance among other factors and the hotel sector has identified several outcomes with regard to the number and interpretation of dimensions guests use to assess perceived hotel service quality. Identified tangibles is a key dimension of service quality in the hospitality industry (Wong, Dean and White, 1999). This research reveals that consumers expects the hotel to have visually appealing facilities and visually appealing materials. The hotel should have visually appealing facilities and materials for guests to look at and provide a sense class and appeal towards them as they are looking for that in luxury hotels. Thus, the correlation of tangible is significant to customer satisfaction.

Moreover, this study reveals that responsiveness, empathy and reliability which are components of SERVQUAL model measuring service quality construct of this research framework respectively show that there is no significant relationship of them with customer satisfaction. The result of this research is incompatible with the study conducted by Al Khattab and Aldehayyat (2011) which showed that empathy was the most important dimension in predicting hotel customer's overall service quality evaluations and the results showed a positive statistical significance between the dimensions of reliability and responsiveness of SERVQUAL model measuring service quality with customer satisfaction. However, this result is partially supported by Karunaratne and Jayawardena (2010) as they showed that customers were happy with the service dimensions of tangibility, responsiveness and assurance of the hotel, but the perceptions and expectations of the customers indicated a negative difference in reliability and empathy dimensions. The hotel had not been capable of fulfilling the customers' satisfaction in reliability and empathy dimensions of SERVQUAL model which turned out with a difference of -0.027 . This research reveals that hotels should still work on those of factors despite there is no significant relationship between them and customer satisfaction. For responsiveness, the hotel staff should be willing to serve the guest and the eagerness should be seen. The hotel staff should be available for and be flexible with guest demands because it provides a sense of caring and feeling of being in the comfort of luxury. For empathy, the hotel staff needs to have knowledge about guest questions such as surrounding areas, hotel facilities, and etc. The hotel staff needs to provide the guest personal attention, have best interest of them at heart, understand guest specific needs such as Muslim rituals of food as the service should be personalised to provide repetition in purchase. The hotel staff needs to be competent because customers pay for professionalism. For reliability, the hotel needs to 
provide the service in promised matter of time, error free service and service without delay such as delivering the order in the time frame given to the guest, without making any mistakes and on time respectively.

On top of that, the hypothesis related to the relationship of assurance of SERVQUAL model shows positive significant on customer satisfaction. This dimension is consistent with Karunaratne and Jayawardena (2010) which showed that luxury hotels resulted positive significance with regard to the customers' perceptions and expectations of the assurance dimension. It confirms that the 5-star hotel customers' expectations had been meet and they were satisfied about the assurance dimension of luxury hotel services. Minh et al. (2015) also supported the claim that assurance dimension has positive correlation to customer satisfaction with its positive significance and the highest dimension scored in that research. This research reveals that the consumers would need feelings of safety and security during their stay at the hotel, the hotel staff needs to provide knowledge to guest information about surrounding areas and the hotel staffs are courteous and polite. The result played out well because of factors that Hong Kong is one of safest cities in the world, the staff of the hotel has good information for guest about surrounding areas as part of their tourism activities, and consumers of hotels expect good assurances from the luxury hotels. Thus, the correlation of assurance is significant to customer satisfaction.

Furthermore, this research revealed that service quality as a whole affects customer satisfaction and it resulted the greatest correlation in this study despite having three rejected hypotheses of three components affecting customer satisfaction. The research contradicts with Minh et al. (2015) results, they demonstrated that the service quality is a strong driver for customer satisfaction in hotel service in Vietnam. Among five SERVQUAL model dimensions, responsiveness, empathy, reliability and assurance represent the significant impacts on the customer satisfaction whereas tangible is the only one does not reveal this clear impact. Whereas this study results opposite of theirs, tangible and assurance are the only two dimensions out of the service quality construct showed positive impact on customer satisfaction. This clearly indicates service quality in other words (SERVQUAL model) is not a strong driver for customer satisfaction in Hong Kong luxury hotels. Wong, Dean and White (1999) indicates that service quality should be based on dimension scores and managers of the hotels will get much more useful data. Furthermore, this research reveals that the services provided at the hotel meets the guest expectation and the guest is satisfied with hotel services. The hotels are providing services which are meeting the guest expectation and making the guest being satisfied with the hotel services such as visually appealing facilities, assurance for safety, and etc. Thus, the correlation of service quality is significant to customer satisfaction.

\section{Limitations and Recommendations}

Although the results of this research show that responsiveness, empathy and reliability do not directly affect customer satisfaction, the study is subjected to two limitations. First, the sample collected is specifically for Hong Kong luxury hotel customers and further research is needed to compare and contrast the similarities and differences among different geographical locations. Therefore, the scope of the research cannot cover luxury hotel customers in other countries / cities. Second, the sample demographic characteristics are not precise due to the time constraints and further research is needed to expand the horizon for better results of the luxury hotel customers. Therefore, the scope of the research cannot cover the nationality of each luxury hotel customers instead the research covered the region.

\section{Conclusion}

The study had examined the factors affecting customer satisfaction in Hong Kong luxury hotels. Eight constructs of the research framework are based on the literature reviews about perceived quality, service quality, and customer satisfaction respectively. The analytical results of this study provide insights into the factors affecting customer satisfaction in Hong Kong luxury hotels. Seven hypotheses were created and four hypotheses are accepted. Three hypotheses are found rejected. In addition, the statistical significant results in this study give empirical evidence to the relationships among perceived quality and service quality, tangibles and customer satisfaction, assurance and customer satisfaction, service quality and customer satisfaction. 


\section{References:}

1. Al Khattab, S. A., and Aldehayyat, J. S. (2011). Perceptions of service quality in Jordanian hotels. International Journal of Business and Management, 6(7), 226.

2. Anderson, E. W., Fornell, C., and Lehmann, D. R. (1994). Customer satisfaction, market share, and profitability: Findings from Sweden. Journal of marketing, 53-66.

3. BLEŠIĆ, I., Ivkov-Džigurski, A., Stankov, U., STAMENKOVIĆ, I., and Bradić, M. (2011). Research of expected and perceived service quality in hotel management. Revista de turism studii si cercetari in turism, (11), 6-14.

4. Coakes, S. J., Steed, L. and Price, J. (2008). SPSS Version 15.0 for Windows: Analysis without Anguish, John Wiley and Sons Australia, Ltd.

5. Debasish, S. S., and Dey, M. S. (2015). Customer perceptions of service quality towards luxury hotels in Odisha Using Servqual Model. International Journal of Research in Business Studies and Management, 2(9), 1-9.

6. Dominici, G., and Guzzo, R. (2010). Customer satisfaction in the hotel industry: A case study from Sicily.

7. Edvardsson, B. (2005). Service quality: beyond cognitive assessment. Managing Service Quality: An International Journal, 15(2), 127-131.

8. Fornell, C., \& Larcker, D. F. (1981). Evaluating structural equation models with unobservable variables and measurement error. Journal of Marketing Research, 18(1), 39-50.

9. Ghobadian, A., Speller, S., and Jones, M. (1994). Service quality: concepts and models. The International journal of quality and reliability management, 11(9), 43-66.

10. Gumussoy, C. A., and Koseoglu, B. (2016). The effects of service quality, perceived value and price fairness on hotel customers' satisfaction and loyalty. Journal of Economics, Business and Management, 4(9), 523-527.

11. Hair, J. F., Black, B., Babin, B., Anderson, R. E. and Tatham, R. L. (2005), Multivariate Data Analysis, Prentice Hall.

12. Hulland, J. (1999). Use of partial least squares (PLS) in strategic management research: A review of four recent studies. Strategic Management Journal, 20(2), 195-204.

13. Karunaratne, W. M. K. K., and Jayawardena, L. N. A. C. (2010). Assessment of customer satisfaction in a five star hotel-A case study. Tropical Agricultural Research, 21(3), 258-265.

14. Lai, F., Griffin, M., and Babin, B. J. (2009). How quality, value, image, and satisfaction create loyalty at a Chinese telecom. Journal of business research, 62(10), 980-986.

15. Marković, S., and Raspor Janković, S. (2013). Exploring the relationship between service quality and customer satisfaction in Croatian hotel industry. Tourism and Hospitality Management, 19(2), 149164.

16. Marković, S., and Raspor, S. (2010). Measuring Perceived Service Quality Using servqual; A Case Study of the Croatian Hotel Industry; Merjenje zaznane kakovosti storitev s pomočjo modela servqual; primer hrvaške hotelske dejavnosti. Management, 5(3), 195-209.

17. Minh, N. H., Thu Ha, N., Chi Anh, P., \& Matsui, Y. (2015). Service quality and customer satisfaction: A case study of hotel industry in Vietnam. Asian Social Science, 11(10), 73-85.

18. Parasuraman, A., Zeithaml, V. A., and Berry, L. L. (1988). Servqual: A multiple-item scale for measuring consumer perc. Journal of retailing, 64(1), 12.

19. Tabaku, E., \& Cerri, S. (2016). An assessment of service quality and customer satisfaction in the hotel sector. Faculty of Tourism and Hospitality Management in Opatija. Biennial International Congress. Tourism and Hospitality Industry, 480-489.

20. Wong, A., Dean, A., and White, C. (1999). Analysing service quality in the hospitality industry. Managing Service Quality. 9. 136-143.

21. Yang, Z., and Peterson, R. (2004). Customer perceived value, satisfaction, and loyalty: The role of switching costs. Psychology \& Marketing, 21(10), 799-822.

22. Zeithaml, V. (1988). Consumer Perceptions of Price, Quality, and Value: A Means-End Model and Synthesis of Evidence. Journal of Marketing, 52(3), 2-22. 